\title{
ULTRA-HIGH TEMPERATURE EFFECT ON BIOACTIVE COMPOUNDS AND SENSORY ATTRIBUTES OF ORANGE JUICE COMPARED WITH TRADITIONAL PROCESSING
}

\author{
Gaḷina Zvaigznè ${ }^{1, \#}$, Daina Kārklina ${ }^{1}$, Joerg-Thomas Moersel ${ }^{2}$, Sasha Kuehn², \\ Inta Krasnova ${ }^{3}$, and Dalija Segliṇa ${ }^{3}$ \\ ${ }^{1}$ Faculty of Food Technology, Latvia University of Agriculture, 2 Lielā Str., Jelgava, LV-3001, LATVIA \\ 2 Untersuchungs-, Beratungs-, Forschungslaboratorium GmbH, An der Mühle 1, Altlandsberg 15345, GERMANY \\ ${ }^{3}$ Latvia State Institute of Fruit Growing, 1 Graudu Str., Dobele, LV-3701, LATVIA \\ \# Corresponding author, g.zvaigzne@inbox.Iv
}

Communicated by Daina Kārkliṇa

\begin{abstract}
Orange juices are an important source of bioactive compounds. Because of its unique combination of sensory attributes and nutritional value, orange juice is the world's most popular fruit juice. Orange (Citrus sinensis) juice of Greek Navel variety was used in this study. The impact of Conventional Thermal Pasteurisation $\left(94^{\circ} \mathrm{C} / 30^{\prime}\right)(\mathrm{CTP})$ and alternative Ultra-High Temperature (UHT) $\left(130^{\circ} \mathrm{C} / 2^{\prime}\right)$ processing on bioactive compounds and antioxidant capacity changes of fresh Navel orange juice was investigated. Sensory attributes of processed juices were evaluated. Results showed that using technologies CTP and UHT orange juice Navel significantly changed vitamin C concentration in comparison with fresh orange juice. The highest concentration of antioxidants (vitamin C, total phenols, hesperidin and carotenoids) was observed in orange juice Navel produced by UHT technology. Sensory results indicated that characteristics of the orange juice obtained using UHT technology were more liked than the CTP heat treated juice. UHT technology emerges as an advantageous alternative process to preserve bioactive compounds in orange juice.
\end{abstract}

Key words: orange juice, bioactive compounds, UHT processing technology.

\section{INTRODUCTION}

Orange fruits and orange juices are an important source of biologically active compounds including antioxidants such as vitamins, flavonoids, phenolic compounds, and pectin that are important for human nutrition (Jayaprakasha and Patil, 2007). Thermal processing continues to be the most widely used method of preserving and extending the shelflife of foods (Awuah et al., 2007). The primary purpose of pasteurisation in food processing is to destroy pathogenic organisms and also inactivate enzymes. Spoilage microorganisms and native enzymes can be inactivated by thermal treatment but such treatment can cause irreversible damage to the sensory attributes (Braddock, 1999) as well as reduction of nutrients. Orange juice is traditionally pasteurised with either tubular or plate-type heat exchangers that are heated either by steam or hot water. Commercially, the juice is rapidly heated to $90-99{ }^{\circ} \mathrm{C}$ and heating usually takes about 30 seconds or less and the juice is heated rapidly without local overheating (Braddock, 1999; Kulwant et al., 2012). Ultra-high temperature (UHT) sterilises food by heating it above $135{ }^{\circ} \mathrm{C}$, the temperature required to kill spores in juices, for 1 to 2 seconds. UHT is most commonly used in milk production, but the process is also used for fruit juices, cream, soy milk, yogurt, wine, soups, honey, and stews. UHT processing is an attractive technique to extend the shelf-life and raise the consumer safety while maintaining the fresh quality of orange juice. The aim of this work was to compare impact of two methods of the processing - Conventional Thermal Pasteurisation $\left(94{ }^{\circ} \mathrm{C} 30 \mathrm{~s}\right.$ ) and Ultra-High Temperature processing $\left(130{ }^{\circ} \mathrm{C} 2 \mathrm{~s}\right)$ - on bioactive compounds and antioxidant capacity of fresh unfrozen orange juice Navel.

\section{MATERIALS AND METHODS}

Materials used for experiments. The study was carried out in laboratories of the Latvia University of Agriculture, Jelgava, Latvia State Institute of Fruit Growing, Dobele, Latvia; and in Untersuchungs-, Beratungs-, Forschungslaboratorium GmbH, Altlandsberg, Germany in 2015. 
The orange (Citrus sinensis) juice of Greek Navel variety from the S.A. Biofresh production line of a commercial juice plant in Laconia Southern Greece was obtained. No thermal treatment was applied. The juice was immediately frozen in a forced circulation freezer and kept at $-20{ }^{\circ} \mathrm{C}$ until using. All samples of the frozen orange juice were defrosted. UHT processing and conventional thermal processing (CTP) were conducted on the same day for each experiment. All samples were compared in terms of bioactive compounds and consumer acceptance.

UHT processing. UHT processing of orange juice was carried out using a laboratory pilot scale pasteuriser with a tubular heat exchanger (Armfield FT74, HTST/UHT Processing Unit, Hampshire, England) at $130{ }^{\circ} \mathrm{C}$ for $2 \mathrm{~s}$.

CTP. CTP of orange juice was carried out using the laboratory equipment AES-110 RFG (Raypa, Spain) at $94{ }^{\circ} \mathrm{C}$ for $30 \mathrm{~s}$. Treatment conditions were comparable to those used in case of orange juice in commercial practices: heating from $90-99^{\circ} \mathrm{C}$ for $10-30 \mathrm{~s}$ (Braddock, 1999; Nirman et al., 2012).

All samples of processed juice were filled in glass bottles of $150 \mathrm{ml}$ capacity with screw-cup closures. Five bottles of each juice were kept for sensory evaluation and two samples of each juice were immediately sent to laboratory for the determination of total soluble solids, $\mathrm{pH}$, titration acidity, vitamin $\mathrm{C}$, total phenols, total carotenoids and antioxidant activity. The sensory evaluation was conducted within one week after the production, using a hedonic scale test by 14 trained panellists who were the analysts in the UBF GmbH Company.

Analytical methods. The total soluble solids concentration ( ${ }^{\circ}$ Brix) was determined at temperature $20{ }^{\circ} \mathrm{C}$ with a digital refractometer ATAGO N20 (deviation of measuring instrument face value $\pm 0.1 \%$ ) (ISO 2173:2003);

The total acid total soluble solids concentration (\%) was determined by titrating with $0.1 \mathrm{~N} \mathrm{NaOH}$ (ISO 750:1998);

L-ascorbic acid (vitamin C) (mg.100 ml-1) was determined according to standard (LVS EN 14130:2003);

Total phenol total soluble solids concentration (mg.100 $\mathrm{ml}^{-1}$ ) was determined by the Folin-Ciocalteu method and measured at wavelength $760 \mathrm{~nm}$ and expressed as gallic acid equivalents (ISO14502-1:2005);

Flavonoid, concentration of hesperidin $\left(\mathrm{mg} \cdot 100 \mathrm{ml}^{-1}\right)$ was determined by high-efficiency liquid chromatography (HPLC), (Shimadzu, Japan).

The concentration of total carotene was determined by using a spectrometer UV-1650-PC at wavelength $450 \mathrm{~nm}$, German standard methods (DGF) C-III (1975).

Antioxidant capacity (AOC) assay was studied applying three spectrometry methods. Free-radical scavenging-effect on 2.2-diphenyl-1-picrylhydrazyl (DPPH), ferric reducing antioxidant power (FRAP) according to the method (Cao et al., 2012) and the method adapted from Rice-Evans and Miller (1994), which is based on the inhibition by antioxidants of the radical cation of 2.2-azinobis-(3-ethylbenzothiazoline-6-sulphonic acid) (ABTS), which has a characteristic absorption maximum at $734 \mathrm{~nm}$. All data were then expressed as Trolox equivalents (TE).

Sensory evaluation. Orange juices were evaluated by using the hedonic rating scale according to ISO 4121:1987 (Sensory analysis - Guidelines for the use of quantitative response scales). Consumer acceptability was evaluated by 14 trained panellists (10 female, 4 male) from 21 to 58 years of age. Prior to sensory evaluation orange juice samples were refrigerated, randomly coded and served $(20 \mathrm{ml})$ at $18{ }^{\circ} \mathrm{C}$ together with non-salted crackers and still water. The panellists were seated separately in booths in order to allow an unbiased evaluation of the sensory attributes. Samples of orange juice obtained by UHT and CTP processing technologies were compared in terms of aroma and flavour and overall acceptability on a 9-point hedonic scale. For aromaflavour and overall acceptability 1 was the lowest and 9 was the highest score.

Statistical analysis. The data processing was carried out by Microsoft Excel for Windows 7.0 variance analysis and the SPSS program SPSS 15 package.

\section{RESULTS}

To compare the impact of different processing technologies, the main bioactive compounds present in orange juice were quantified.

Effect of processing methods on bioactive compounds in orange juice Navel. The soluble solids ( ${ }^{\circ}$ Brix), total acidity (TA) and $\mathrm{pH}$ values of fresh unfrozen, CTP and UHT processed orange juice Navel are provided in Table 1. There were no significant differences in these values after CTP and UHT treatments in comparison with the fresh unfrozen juice $(p>0.05)$.

Figure 1 shows concentration of vitamin $\mathrm{C}$ in orange juice Navel after CTP and UHT processing. In fresh unfrozen orange juice Navel the concentration of vitamin C was 53.65 $\mathrm{mg} \cdot 100 \mathrm{ml}^{-1}$. CTP and UHT processed juices had signifi-

Table 1

EFFECT OF CONVENTIONAL THERMAL PASTEURIZATION AND ULTRA-HIGH TEMPERATURE PROCESSING ON PHYSICOCHEMICAL CHARACTERISTIC OF NAVEL ORANGE JUICE

\begin{tabular}{l|c|c|c|c}
\hline $\begin{array}{c}\text { Samples of orange } \\
\text { juice Navel }\end{array}$ & $\begin{array}{c}\text { Total soluble } \\
\text { solid, }{ }^{\circ} \text { Brix }\end{array}$ & $\begin{array}{c}\text { Total acidity, } \\
\%\end{array}$ & $\mathrm{pH}$ & Ratio \\
\hline $\begin{array}{l}\text { Fresh unfrozen } \\
11.43 \pm 0.00^{\mathrm{a}}\end{array}$ & $0.79 \pm 0.05^{\mathrm{a}}$ & $3.65 \pm 0.00^{\mathrm{a}}$ & 13.67 \\
$\begin{array}{l}\text { Conventional ther- } \\
\text { mal pasteurized }\end{array}$ & $11.58 \pm 0.00^{\mathrm{a}}$ & $0.82 \pm 0.00^{\mathrm{b}}$ & $3.65 \pm 0.01^{\mathrm{b}}$ & 14.54 \\
$\begin{array}{l}\text { Ultra-High Tem- } \\
\text { perature processed }\end{array}$ & $11.60 \pm 0.00^{\mathrm{a}}$ & $0.84 \pm 0.04^{\mathrm{a}}$ & $3.55 \pm 0.01^{\mathrm{b}}$ & 14.03 \\
\end{tabular}

Column values with different online letters $(\mathrm{a}, \mathrm{b})$ differ $(p<0.05)$.

*Results were presented as "means" \pm standard error $(n=4)$ 


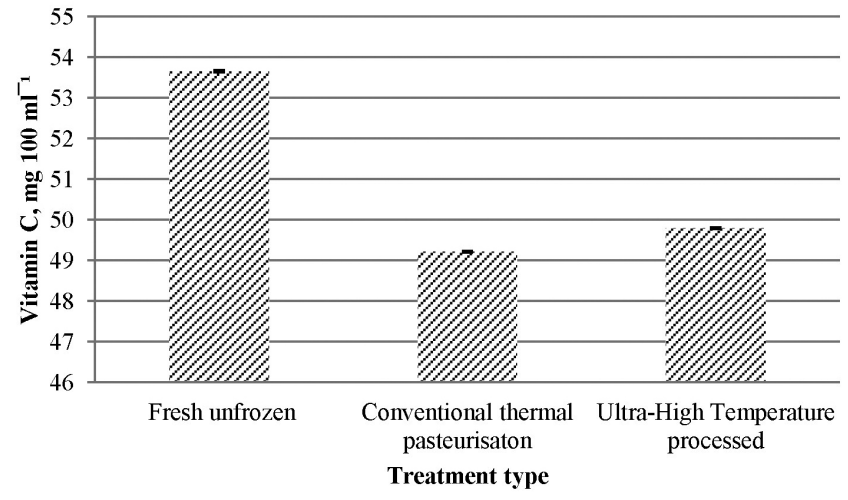

Fig. 1. Vitamin C concentration in Navel orange juice for each treatment assayed.

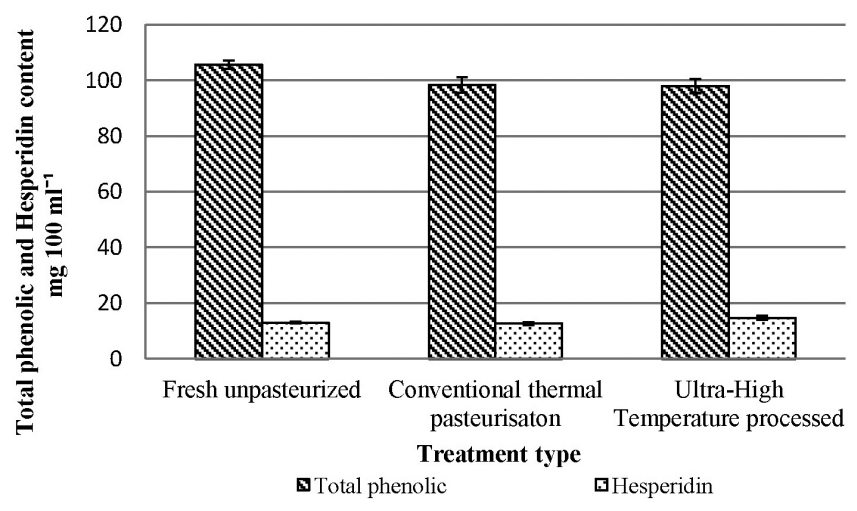

Fig. 2. Total phenolic compounds and hesperidin concentration in Navel orange juice for each treatment assayed.

cant difference in values of vitamin $\mathrm{C}$ concentration in comparison with freshly squeezed orange juice. In both (CPT and UHT) processed juices, the content of vitamin $\mathrm{C}$ decreased to 49.21 and $49.79 \mathrm{mg} \cdot 100 \mathrm{ml}^{-1}$, which is about a $9 \%$ and $8 \%$ loss, respectively.

In fresh unfrozen orange juice Navel the total phenol concentration was $105.67 \mathrm{mg} \cdot 100 \mathrm{ml}^{-1}$. Total phenol concentration was slightly $(p>0.05)$ higher $\left(98.39 \mathrm{mg} \cdot 100 \mathrm{ml}^{-1}\right)$ in orange juice processed by CTP compared to the samples obtained by UHT processing (98.04 mg.100 ml-1) (Fig. 2).

The major glycoside flavonoids in citrus are hesperidin. The study results showed $13.02 \mathrm{mg} \cdot 100 \mathrm{ml}^{-1}$ concentration of hesperidin in fresh unfrozen orange juice. The hesperidin concentration (14.81 mg.100 ml $\mathrm{ml}^{-1}$ ) increased in UHT treated orange juice and hesperidin concentration (12.73 $\mathrm{mg} \cdot 100 \mathrm{ml}^{-1}$ ) decreased in CPT processed orange juice compared with fresh unfrozen orange juice (Fig. 2).

The total carotenoid concentration in fresh unfrozen orange juice Navel was $2.26 \mathrm{mg} \cdot 100 \mathrm{ml}^{-1}$. Just after CTP and UHT treatment of orange juices, the total carotenoid concentra-

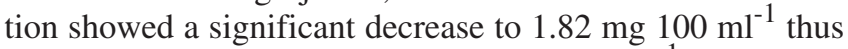
resulting in a $20 \%$ loss, and to $1.95 \mathrm{mg} 100 \mathrm{ml}^{-1}$ thus resulting in $14 \%$ loss, respectively, in comparison with total carotenoid content of fresh orange juice.

Figure 4 presents the results of the AOC of orange juices obtained by CTP and UHT processing. In the DPPH assay,

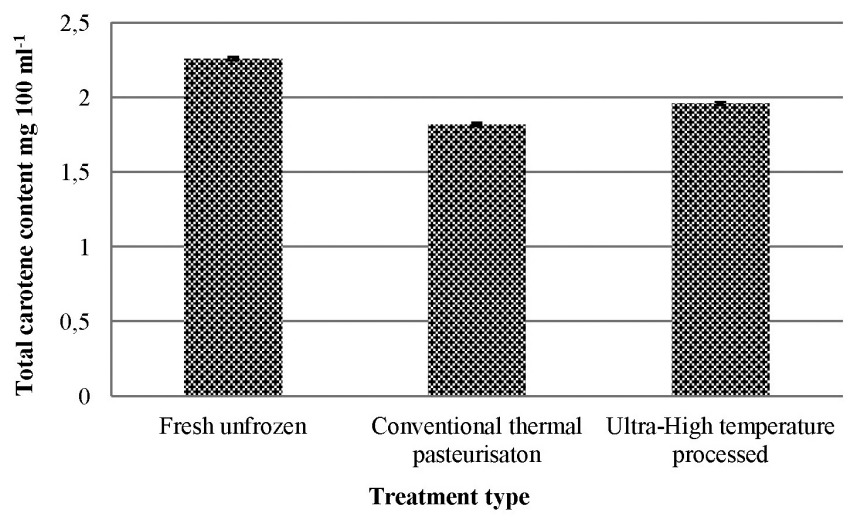

Fig. 3. Total carotene concentration in Navel orange juice for each treatment assayed.

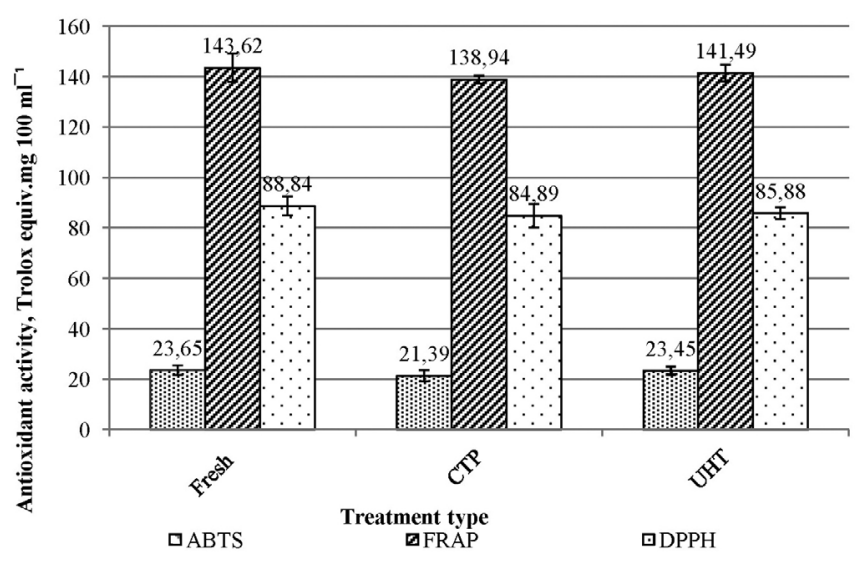

Fig. 4. Antioxidant activity (2.2-azinobis-(3-ethylbenzothiazoline-6sulphonic acid, ferric reducing antioxidant, 2.2-diphenyl-1-picrylhydrazyl) in 'Navel' orange juice for each treatment assayed. Fresh — fresh unfrozen orange juice; CTP - conventional thermal pasteurised orange juice; UHT - orange juice processed at ultra-high temperature ultra-high heated orange juice.

the scavenging activity of Navel orange juice was 88.84 , 85.88 , and $84.89 \mathrm{mg}$ Trolox equiv. $100 \mathrm{ml}^{-1}$ in fresh unfrozen, UHT and CTP processed orange juices, respectively. The AOC was also determined using FRAP assay: values were $143.62,141.49$, and $137.87 \mathrm{mg}$ Trolox equiv. $100 \mathrm{ml}^{-1}$ in orange juice, respectively. The results of AOC obtained by means of ABTS methods in the fresh unfrozen orange juice and the samples after thermal treatments were 23.65, 23.45 , and $21.39 \mathrm{mg}$ of Trolox equiv. $100 \mathrm{ml}^{-1}$, respectively. The chosen methods for AOC determination did not show significant differences $(p>0.05)$ in orange juice samples processed by CTP and UHT technologies. Grouped statistics show that ABTS was correlated directly with the vitamin $\mathrm{C}$, total phenols, carotenoids, and hesperidin $(\mathrm{r}=$ $0.688 ; r=0.563 ; r=0.802 ; r=0.511$, respectively). In the test with $\mathrm{DPPH}^{*}$ radical and by FRAP method clearly correlated $(r=0.993 ; r=0.999 ; r=0.960$ and $r=0.899 ; r=$ 0.961 ; and $r=0.817$ ) with the vitamin $C$, carotenoids and flavonoids respectively.

Effect of UHT and CTP processing on sensory quality of orange juice Navel. Sensory evaluation of fresh defrosted, 
Table 2

SENSORY EVALUATION OF PROCESSING ORANGE JUICE NAVEL

\begin{tabular}{l|c|c}
\hline \multicolumn{1}{c|}{ Samples of orange juice Navel } & Overall & $\begin{array}{c}\text { Flavour and } \\
\text { aroma }\end{array}$ \\
\cline { 2 - 3 } & \multicolumn{2}{|c}{ *Hedonic scale } \\
\hline Fresh unfrozen & 7.8 & 7.5 \\
Conventional thermal pasteurized & 7.4 & 7 \\
Ultra-High Temperature processed & 6.1 & 6.2
\end{tabular}

* Consumer Acceptance Testing $(\mathrm{n}=14)$; 9 point hedonic scale-9 = like extremely; $8=$ like very much; 7 = like moderately; $6=$ like slightly; $5=$ neither like nor dislike; $4=$ dislike slightly; $3=$ dislike moderately; $2=$ dislike very much; and $1=$ dislike extremely.

UHT and CTP processed orange juice Navel in terms of overall and flavour characteristic were determined using a consumer acceptability test based on a 9-point hedonic scale. The results of the study are shown in Table 2. Fresh unfrozen orange juice in terms of overall and flavour and aroma characteristics was located in the "extremely like" part of hedonic scale with 8.5 and 8.1 scores while UHT treated orange juice was evaluated in the "like moderately" part of the hedonic scale with 7.8 and 7.4 scores, respectively. Conventional thermal pasteurised orange juice was evaluated in the "like slightly" part of the hedonic scale with 6.2 (overall) and 6.0 (flavour and aroma) scores, respectively. These results showed that although sensorial characteristics of orange juice Navel did not change adversely after CTP treatment, UHT treated orange juice was significantly more liked than CTP processed orange juice $(p<0.05)$.

\section{DISCUSSION}

According to various references, orange juice can be considered as a rather rich source of vitamin C (Topuz et al., 2005; Klimczak et al., 2007; Melendez-Martinez et al., 2007). The concentration of vitamin $C$ is an important indicator of orange juice quality and nutrition value, and it serves as an indicator that all technological processes, which ensure a high quality of the product, have been applied (Manso et al., 1996; Lee, Coates, 1997; Lee, Chen, 1998; Polydera et al., 2005). Vitamin C is an unstable compound; therefore the stability of this compound is influenced by the degree of heat treatment. It is known that heat treatments may reduce antioxidant activity and concentration of bioactive compounds in juices (Patras et al., 2010). In this study concentration of vitamin $\mathrm{C}$ was significantly lower in both (CPT and UHT) processed juices.

Orange juice is a rich source of bioactive compounds, such as phenols including hesperidin. Gorinshein et al. (2001) reported that total polyphenol concentration in peeled oranges was $154 \pm 10.2 \mathrm{mg} \cdot 100 \mathrm{~g}^{-1}$ of fresh fruits, which is consistent with the results of this study. The total concentration of phenols in orange juices was determined in other studies. Klimczak et al. (2007) determined total polyphenols and individual phenolic compounds in two commercial orange juices. Using HPLC and Folin-Ciocalteu methods they found that concentration of total polyphenols was higher determined by the Folin-Ciocalteu method (684.2 and 634.6 $\mathrm{mg} / \mathrm{L}$ ) compared to the concentration obtained by the HPLC method (226.4 and $202.7 \mathrm{mg} / \mathrm{L})$ in both orange juices. Esteve and Frigola, (2008) did not find significant $(p>0.05)$ differences between orange juices pasteurised by Pulsed Electric Fields (PEF) and High Pressure Processing (HPP) methods; values were higher in case of untreated orange juice. Vanamala et al. (2006) reported phenolic compound concentration of $53.2 \mathrm{mg} \cdot 100 \mathrm{ml}^{-1}$ in MFC (made from concentrate) orange juice and concentration of these compounds (36.49 mg.100 ml-1 was significantly higher compared to the NFC (not from concentrate) orange juice. A slight decrease in the concentration of flavonoids after heat treatment may be due to changes in the structure of vesicles in the orange, permitting a greater extraction of flavanones that is reduced by pasteurisation.

The major glycoside flavonoids in citrus are hesperidin, naringin, and neohesperidin. Hesperidin is a main flavonoid of oranges. Hesperidin concentration of citrus fruit varies with species (Omidbaigi et al., 2002). The results of our study are in a good agreement with results reported by Kanitsar et al., (2001), 127-219 mg per L, and by Tomas-Barberan and Clifford (2000), 104-637 mg per L. In our study the concentration of hesperidin increased in UHT treated orange juice and it decreased in CTP orange juice compared with fresh unfrozen orange juice. This may be due to hydrolysis of the glycoside at high temperature. Also, these results are in agreement with previously reported values (Mouly et al., 1998; Vanamala et al., 2006). Belajova and Suhaj (2004) published a hesperidin level of 44-56 mg per L in commercial orange juices. Robards et al. (1997) and TomasBarberan and Clifford (2000) reported that the hesperidin level in orange juice depended on technological treatment.

Carotenoids are important quality indicators (the colour and nutritional value) for orange juice; some are known for their antioxidant capacity (e.g. $\beta$-carotene and lutein) (Rao and Rao, 2007). The concentration of total carotenoid in fresh unfrozen orange juice Navel was comparable to values found by Lee and Coates (2003), although higher concentration of total carotenoids is reported as well (SanchezMoreno et al., 2005; Gama and Sylos, 2007; Esteve et al., 2009). These results are in agreement with Hyoung and Coates (2003), Lee and Coates (2003), Cortes et al., (2006), Esteve et al., (2009) who also noticed a significant processing effect. Some authors, nevertheless, have reported that processing had no significant effect on the carotenoid profile (Lee and Coates, 2003; Vervoort et al., 2011). Also, there were no significant changes after thermal treatment in a study by Sanchez-Moreno et al. (2005), after HPP treatment by Donsi et al. (1996) and Esteve et al. (2009), and after PEF treatment by Sanchez-Moreno et al. (2005). Plaza et al. (2011) reported that low pasteurisation temperature (LPT) juice did not show carotenoid degradation but after HP treatment the orange juice showed a significant increase in carotenoids $(45.19 \%)$ in comparison to untreated juice. 
They also found that HP juice showed the highest carotenoid concentration among all tested juices.

Antioxidants play a very important role in nutrition. This is caused by their health benefits. Heat treatments may reduce antioxidant capacity and concentration of bioactive compound groups (Patras et al., 2010). In this study, AOC of orange juice after thermal processing was evaluated using the DPPH free radical-scavenging, ferric reducing antioxidant power (FRAP) assays and ABTS radical-cation method. All these methods are recommended by many authors for measuring the antioxidant activity of fruit juices. As can be seen by the used methods of determination, AOC decreased but insignificantly $(p>0.05)$ after CTP and UHT processing technology. No data were found in the literature about antioxidant activity or capacity of UHT processed orange juices. Literature data suggest changes in individual antioxidant values in grape seed extract (Davidov-Pardo et al., 2011), with different treatments of 60,90 , and $120{ }^{\circ} \mathrm{C}$ for 5 , $10,15,30,45$, and $60 \mathrm{~min}$, but no significant changes on total antioxidant capacity were observed after thermal treatment.

The results of the sensory study showed that although both processed juices had no significant differences in physicochemical parameters and the concentration of biologically active substances, the UHT treated orange juice was significantly more pleasant than the CTP treated orange juice. UHT technology emerges as an advantageous alternative process to preserve bioactive compounds in orange juice.

\section{REFERENCES}

Awuah, G. B., Ramaswamy, H. S., Economides, A. (2007). Thermal processing and quality: Principles and overview. Chem. Eng. Proc., 46 (6), $584-602$

Belajova, E., Suhaj, M. (2004). Determination of phenolic constituents in citrus juices: Method of high performance liquid chromatography. J. Food Chem., 86, 339-343.

Braddock, R. J. (eds.) (1999). Handbook of Citrus By-Products and Processing Technology. John Willey and Sons, New York. 247 pp.

Cortes, C., Torregrosa, F., Esteve, M. J., Frkgola, A. (2006). Carotenoid profile modification during refrigerated storage untreated and pasteurised orange juice and orange juice treated with high-intensity pulsed electric fields. J. Agr. Food Chem., 54 (17), 6247-6254.

Donsi, G., Ferrari, G., Di Matteo, M. (1996). High pressure stabilization of orange juice: Evaluation of the effects of process conditions. Italian J. Food Sci., 8 (2), 99-106.

Esteve, M. J., Barba, F. J, Palop, S., Frigola, A. (2009). The effects of non-thermal processing on carotenoids in orange juice. Czech J. Food Sci., 27, 304-306.

Esteve, M. J., Frigola, A. (2008). The effects of thermal and non-thermal processing on vitamin C, carotenoids, phenolic compounds and total antioxidant capacity in orange juice. Tree and Forestry Science and Biotechnology, 2 (Special Issue 1), 128-134.

Gama, J. T., Sylos, C. M. (2005). Major carotenoid composition of Brazilian Valencia orange juice: Identification and quantification by HPLC. Food Res. Int., 38, 899-903.

Gorinshein, S., Martin-Belloso, O., Park, Y. S., Haruenkit, R., Lojek, A., Ciz, M., Caspi, A., Libman, I., Trakhtenberg, S. (2001). Comparison of some biochemical characteristics of different citrus fruits. Food Chem., 74 (3), 309-315.

Hyoung, S. L. Coates, G. A. (2003). Effect of thermal pasteurization on Valencia orange juice colour and pigments. Lebensmittel-Wissenschaft and Technologie, 36 (1), 153-156.

Jayaprakasha, G. K., Patil, B. S. (2007). In vitro evaluation of the antioxidant activities in fruit extracts from citron and blood orange. Food Chem., 101, 410-418.

Kanitsar, K., Arce, L., Rios, A., Valcarcel, M. (2001). Determination of phenolic constituents in citrus samples by online coupling of a flow system with capillary electrophoresis. Electrophoresis, 22, 1553-1565.

Klimczak, I., Malecka, M., Szlachta, M., Gliszczynska-Swiglo, A. (2007). Effect of storage on the content of polyphenols, vitamin $\mathrm{C}$ and theantioxidant activity of orange juices. J. Food Compos. Anal., 20 (3-4), 313-322.

Kulwant, S. S., Kuldip, S. M., Jiwan, S. S. (2012). Processing of citrus juices. In: Sinha, N. K., Sidhu, J. S., Barta, J., Wu, J. S. B., Cano, M. P. (eds.). Handbook of Fruits and Fruit Processing. John Wiley and Sons, Ltd. Publishers, pp. 489-534.

Lee, H. S., Chen, C. S. (1998). Rates of vitamin C loss and discoloration in clear orange juice concentrate during storage at temperatures of $4-24^{\circ} \mathrm{C} . J$. Agricult. Food Chem., 46 (11), 4723-4727.

Lee, H. S., Coates, G. A. (1997). Vitamin C in processed Florida citrus juice product from 1986-1995 survey. J. Agricult. Food Chem., 45, 2550-2555.

Lee, H. S. Coates, G. A. (2003). Effect of thermal pasteurization on Valencia orange juice color and pigments. LWT Food Sci. Technol., 36, (1), $153-156$.

Melendez-Martinez, A. J., Britton, G., Vicario, I. M., Heredia, F. J. (2007). Provitamin A carotenoids and ascorbic acid contents of the different types of orange juices marketed in Spain. Food Chem., 101 (1), 177-184.

Mouly, P., Gaydou E. M., Auffray, A. (1998). Simultaneous separation of flavanone glycosides and polymethoxylated flavones in citrus juices using liquid chromatography. J. Chromatogr., 800 (2), 171-179.

Omidbaigi, R., Nasiri, M. F., Sadr, Z. B., Kock, O. (2004). Hesperidin in citrus species, quantitative distribution during fruit maturation and optimal harvesting time. Nat. Prod. Radiance, 3 (1), 12-15.

Plaza, L., Crespo, I., de Pascual-Teresa, S., De Ancos, B., Sanchez-Moreno, C., Munoz, M., Cano, M.P. (2011). Impact of minimal processing on orange bioactive compounds during refrigerated storage. Food Chem., 124 (2), 646-651.

Polydera, A. C., Stoforos, N. G., Taoukis, P. S. (2005). Quality degradation kinetics of pasteurised and high pressure processed fresh Navel orange juice: Nutritional parameters and shelf life. Innov. Food Sci. Emerg. Technol., 6 (1), 1-9.

Rao, A. V. Rao, L. G. (2007). Carotenoids and human health. Pharmacol. Res., 55, 207-216.

Robards, K., Li, X., Antolovich, M., Boyd, S. (1997). Characterisation of cit$\underline{\text { rus by }}$ chromatographic analysis of flavonoids. J. Sci. Food Agricult., 75 (1), $\frac{87}{87-101 .}$

Sanchez-Moreno, C., Plaza, L., De Ancos, B., Cano, M. P. (2005). Impact of high-pressure and traditional thermal processing of tomato puree on carotenoids, vitamin C and antioxidant activity. J. Sci. Food Agricult., 86, 171-179.

Tomas-Barberan, F. A., Clifford, M. N. (2000). Flavanones, chalcones and dihydrochalcones - nature, occurrence and dietary burden. J. Sci. Food Agricult., 80, 1073-1080.

Topuz, A., Topakci, M., Canakci, M., Akinci I., Ozdemir, F. (2005). Physical and nutritional properties of four orange varieties. J. Food Eng., 66, 519-523. 
Vanamala, J., Reddivari, L., Yoo, K. S., Pike, L. M., Patil, B. S. (2006). Vari$\underline{\text { ation in the content of bioactive flavonoids in different brands of orange }}$ and grapefruit juices. J. Food Compos. Anal., 19, 157-166.

Received 3 October 2016

Accepted in the final form 16 November 2017
Vervoort, L., Van der Plancken, I., Grauwert T., Timmemans, R. A. N., Mastwijk, H. C., Matser, A. M., Hendrickx, M. E., Loey A. V. (2011). Comparing equivalent thermal, high pressure and pulsed electric field process for mild pasteurization of orange juice. Innov. Food Sci. Emerg. Technol., 12 (4), 466-477.

\section{ULTRA AUGSTAS TEMPERATŪRAS IETEKME UZ APELSĪNU SULAS BIOLOĢISKI AKTĪVĀM VIELĀM UN APELSĪNU SULAS SENSORAJĀM İPAŠİ̄BĀM, SALĪDZINĀJUMĀ AR TRADICIONĀLO APSTRĀDI}

Apelsīnu sulas ir svarīgs biolog̊iski aktīvo savienojumu avots. Pateicoties tās unikālajām īpašībām un uzturvērtības kombinācijai, apelsīnu sula ir vispopulārākā aug̣̣u sula pasaulē. Šajā pētījumā tika izmantota Grieķijas šķirnes Navel apelsīnu sula (Citrus sinensis). Tika pētīta ḷoti augstas temperatūras apstrādes $\left(130{ }^{\circ} \mathrm{C} / 2^{\prime}\right)(U H T)$ iedarbība uz bioḳīmiskiem aktīviem savienojumiem un antioksidantu izmaiņas Navel škirnes svaigā atkausētā apelsīnu sulā salīdzinājumā ar tradicionālo apstrādes metodi $\left(94{ }^{\circ} \mathrm{C} / 30^{\prime}\right)(C T P)$. Rezultāti parādīja, ka apelsīnu sulā Navel, kas apstrādāta ar UHT un CTP tehnolog̣iju, C vitamīna saturs ir samazinājies, taču šì samazinājuma vērtības bija nenozīmīgas salīdzinājumā ar vitamīna $\mathrm{C}$ daudzumu svaigā apelsīnu sulā. Vislielākais antioksidantu saturs (C vitamīns, fenolu kopējais daudzums, hesperidīni un karotinoīdu kopējais daudzums) tika atrasts apelsīnu sulā Navel, kura bija apstrādāta, izmantojot UHT tehnoloǵiju. Sensoriskie rezultāti parādīja, ka apelsīnu sula, kura apstrādāta, izmantojot $U H T$ tehnoloğiju, bija populārāka nekā sula, kura tika apstrādāta ar CTP tehnoloğiju. 